\title{
Project Manager Role in Project Management Success
}

\section{Abdurrahman Abubaker Gasemagha, Tan Owee Kowang}

To Link this Article: http://dx.doi.org/10.6007/IJARBSS/v11-i3/9230 DOI:10.6007/IJARBSS/v11-i3/9230

Received: 21 January 2021, Revised: 23 February 2021, Accepted: 10 March 2021

Published Online: 26 March 2021

In-Text Citation: (Gasemagha \& Kowang, 2021)

To Cite this Article: Gasemagha, A. A., \& Kowang, T. O. (2021). Project Manager Role in Project Management Success. International Journal of Academic Research in Business and Social Sciences, 11(3), 1345-1355.

Copyright: $\odot 2021$ The Author(s)

Published by Human Resource Management Academic Research Society (www.hrmars.com)

This article is published under the Creative Commons Attribution (CC BY 4.0) license. Anyone may reproduce, distribute, translate and create derivative works of this article (for both commercial and non-commercial purposes), subject to full attribution to the original publication and authors. The full terms of this license may be seen at: http://creativecommons.org/licences/by/4.0/legalcode

Vol. 11, No. 3, 2021, Pg. 1345 - 1355

Full Terms \& Conditions of access and use can be found at http://hrmars.com/index.php/pages/detail/publication-ethics 


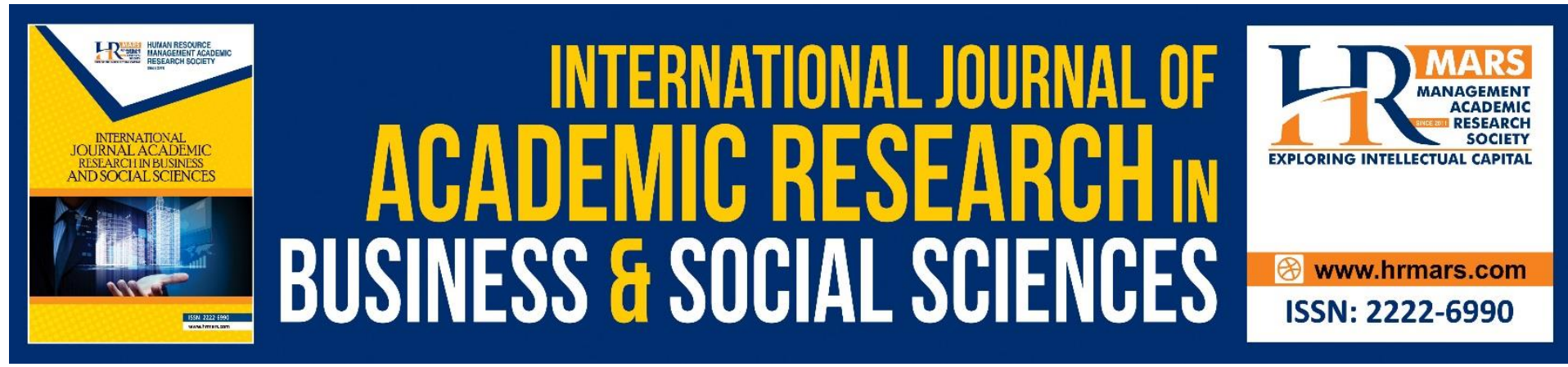

\title{
Project Manager Role in Project Management Success
}

\author{
Abdurrahman Abubaker Gasemagha and Tan Owee Kowang \\ Azman Hashim International Business School, Universiti Teknologi Malaysia, 81310 Johor \\ Bahru, Johor, Malaysia. \\ Email: oktan@utm.my
}

\begin{abstract}
Project management success is an interesting scientific subject from management perspective. Hence, numerous studies had been done by prior scholars to explore and identify the important factors for project success from holistic perspective. In addition, prior research also commonly agreed that project manager plays an important role toward project success. However, there is lack of study that particularly focuses on the roles played by project manager toward project success. Hence, this paper reviews the roles of project manager, reexamines the definition of project management from the project manager perspective and reassesses the relationship between project manager and project management success. Finding from this paper suggests that the capability of project manager on project team management, such as project activities planning, project team member skill evaluation and job distribution; knowledge on the application of project management tools and techniques; and how the project manager deals with political and cultural issues are the key elements for project success.
\end{abstract}

Keywords: Project Manager, Project Management, Project Management Success.

\section{Introduction}

Prior research tends to commonly agree that project manager plays an important role in achieving project goals and expectations (Kerzner, 2013). Hence, "project manager" has been well recognized by prior scholars as one of the important factors for project management success (Loufrani-Fedida and Missonier, 2015). A professional and effective project manager not only brings more prospective toward project success, but also promotes an effective project management process (Meredith and Mantel, 2011). As such, projectbased organizations always focused on identifying, training and sustaining those project managers that could practically manage project towards the success that is in line with the company's vision, mission and strategy. Hence, project-based organization viewed project manager as one of the important company assets.

However, it is important to note that the role of project manager might vary depending on the nature of project, such as the type of project, the stakeholder of the project (public or private), project orientation (interim projects or projects for the market) and number of projects being managed by the project manager at one time (Project Management Institute, 
2013). So, the differences in the nature of project influence the complication of project and how the project should be managed in terms of resource management, time plan management and financial management. Hence, project management is also defined as the approach used by the project manager on application of knowledge, skills, tools and techniques to manage project activities with the ultimate aim to meet the project goals and stakeholders' expectations (Project Management Institute, 2013).

As such, Project manager is a profession that needs to perform various roles to attain a completion of projects amongst the iron triangle constraints for project which are the time, budget and quality, additionally as meeting the essential standard necessities of the project's objectives and stakeholders' expectations (Kerzner, 2013). So, to attain a result of project management success on time, project managers should have an ability of a good knowledge of the way to follow the equipment and strategies of project control (PmBOK, 2017).

This paper aims to study how prior researches dealt with project management success in recent years by taking into account the role of project manager. In addition, this paper aims to outline the importance of skills required for an effective project manager.

\section{Literature Review}

The section reviews the definition of Project manager and Project management, followed by focusing on Project management success. Finally, the relationship between project manager and project management success was reviewed from past literature reviews.

\section{Project Manager}

There are many roles for project managers. Project managers must also have many skills, and have many responsibilities both before and during project implementation leading to project management success (Jones, 2018). So, before project implementation begins, project manager is responsible for scheduling a project plan and budget. During the implementation of the project, his roles include overseeing and managing the project management team he manages and bringing the project to completion. This is because only the project manager knows the full range of project work that needed to plan the success of a project management (Henkel et al., 2019).

In addition, the project manager is responsible for time management, cost, quality, integration, project team members, communication, risk and assets. Therefore, the project manager is the person most responsible for the success of the project management. Both Mulcahy (2018) and PmBOK (2017) Suggested that it is important for project managers to be qualified to motivate and leading members of the project management team to success.

Bizarrias et al. (2020) describe the role of project manager that can affect the perception of successful project management. As a result a skilled project manager responsible for the timely success of the project must be appointed (PmBOK, 2017).

However, to achieve this goal, project managers assess the suitability of project management team members in terms of strengths, weaknesses and lead the project according to understanding, experience, and requirements (Snyder, 2012). Hence, 
responsibilities must be shared and coordinated while project complexity is the responsibility of project management team members and project managers (Burgan \& Burgan, 2014).

Furthermore, Top project managers are also tend to focus on project information, provide guidance of project team, decide whether or not to do work, and build trust and respect for staff / team members who can participate in the project decisions. (Rajbhandar, Rajbhandari, 2016). Therefore, Project managers must learn how to develop their skills and ability in a timely manner, much collaboration, these technologies include leadership, communication, organization, team building, coping and Risks including management, conflict, planning and resource management and skills technologies (Stine, 2018).

In sum, one of the most important interpersonal skills is leadership that a real project manager should have, and the ability to complete a project on time without any delay or budget overrun during the implementation phases, or the project handover (Jones, 2018). Additionally understanding the good behaviour of project managers worldwide and communicating with project management team members is critical to successful and project management. (Arora \& Baronikian, 2013).

\section{Project Management}

Project management is the implementation of responsibilities, knowledge, features, tools, and methods for performing project tasks that meet the needs of the stakeholders / organization and project management. Whereas, Project Management can be influenced by many factors such as political issues, culture environment and project team education level that causes delays or success of project implementation. Although there are delays and failures in project implementation, project management is achieved by adopting and integrating project management processes such as project implementation, program implementation, monitoring, management and project close out (Shahibi et al., 2019). So, this concept contains a set of excellent ways to plan the tasks required to complete a project (Garel, 2013).

In addition, Project management typically refers to the tasks that include defining a project demands, specifying the type of work, allocating required resources, planning and implementation phases, and controlling of the project progress stages (Meredith and Mantel, 2011).

Meanwhile, many do not fully understand the difference between the two distinct concepts of project management and project management success. Therefore, the concept of project management means avoiding excessive costs and achieving certain objectives such as the completion of a given project plan on time based on a set of tasks, responsibilities, and responsibilities performed by the project management team members, and a project manager (Kerzner, 2013). Hence, how can each member of a project management transfer a project management team members a play role as a project manager to achieve success in an area where project success or failure is the cause (Gandomani, 2020).

However, unstable of countries situation cause the government likely to disrupt the political system, so political issues can affect the project management process schedule of implementation plans of the companies (Elakouri, 2018). While, Prasad et al (2013) suggested 
that the culture environment issues in the host country should be taken into account by companies, including aspects of project management that may affect project implementation phases.

(Prasad et al., 2013), also proposed a structure that taken into account for addressing a particular culture environment factors.

Henkel et al. (2019) they argued that organizations offering project management, academic or educational qualifications should adopt a project management approach that values the role of project managers more. Hence, Project managers need to mentor project team members, work well together, and affects on other stakeholders (Hardy-Vallee, 2012).

Prior researchers have found that project management commonly deals with commencement of project, planning, scheduling of pre-implementation phase, then managing and monitoring, controlling of all the project activity phases in order to achieve the organization objectives. Hence, Project management requires a member of the project management team who is competent and responsible for the management of the project from start to finish and who has the ability to do project management successfully.

\section{Project Management Success}

A few decades ago, project management (PM) has become the most widely used management model in organizations (Huemann, et al., 2017). Hence, this situation arises because you have to manage your project to succeed in a complex and problematic environment ( Gemün den et al., 2018). While the Project Management Centre has developed a success project management technical model (PMI, 2013). and the International Project Management Association Competence Baseline (Loufrani-Fedida and Missonier, 2015).

Undoubtedly, project management success demands that a Project managers need to have the technical ability and skills to manage a typical of project iron triangle in terms of time, quality and cost to achieve the objectives of a project management success. Hence, these requirements provide the leadership necessary to succeed in a wide variety of rapidly changing projects that meet the stakeholders' expectations of global market who interact with increasingly cultures diversity which means important to success (Lindblad, 2014).

In this context, the role of project manager is an even more important starting point for achieving better project management success (Miterev et al., 2017). As a result, and to be more effective in managing organizational projects, the interest in job responsibilities, skills and qualifications of project managers has increased recently, with a focus on the role of project managers and their skills to be enable the project management success (Chipulu et al., 2013; Loufrani, Missonier, 2015).

In sum, nowhere is the responsibility of interpersonal skills, within the ability of project manager more important than managing the project of any company/ organization's to success. As a result, the success of a project depends on the project managers who have leadership skills and use them to form a project management team and openly lead the team to meet project management requirements during implementation phases (Dow \& Taylor, 2015). 


\section{The Relationship between Project Manager and Project Management Success}

Organizations and companies are more likely to embrace the skills and responsibilities of project managers for effective and success project management demands, hence, there are many evaluation tools available, including project management team skills, education levels, political issues, and culture environment, that allow project managers to evaluate the strengths and weaknesses of a project thus, almost all project management success depends on project manager role leading project management team (Henkel et al., 2019). Genuinely, successful project management requires the organization to have an effective project manager with advanced ability, skills to fulfil the needs of the project team management members, and needs of stakeholders through a project's implementation phases (Murthy \& Sreenivas, 2017). Therefore, skills, education and the ability of the project manager to under work pressure are essential to guarantee project management success at the right time (Henkel et al., 2019).

Project management success was introduced as complete set of tasks necessary to achieve the goals of project management, consistent with requirements of organization/company to complete the project within the time, within cost, within quality and performance, hence project management is a significant field established for monitoring and controlling during all project implementation phases, as a guarantee for project handover without overruns, and project management success (Shahibi et al., 2019).

Additionally, Taylor et al. (2012) stated that large projects tend to be complex and risky such as infrastructure mega projects. Consequently, these projects require a competent project manager, a large project management team, and better communication; this reduces the project workload and increases the chances of successfully managing a project. Conversely, (Sanchez et al., 2017) stated that a major project that takes over a year of execution have a positive impact on the skill development of project management teams and project managers, hence impact the positive future outcomes of the project leadership.

Alvarenga et al., (2018) stated that the project manager has a direct influence on the final implementation of the project. Thus, project managers in project management organizations develop their skills in project management in terms of planning, implementation, and controlling. Hence, how to effectively manage project activities to success as long as this is a specialization requiring advanced training and education expertise ( Shahibi et al., 2019).

However, another aspect of successful project management relates to success factors such as political issues and the cultural environment as mentioned by (Regaliza, 2017; Rolstadås, 2014). Furthermore, (Turner, (2014) lists some conditions necessary for project management success. One of these conditions is to maintain a mutual relationship between the project owner (stakeholders) and the project manager and empower the project manager by some advantages. As a result, all of these factors have the direct relationships required for successful project management; stakeholder management can vary depending on project management and successful project management (Takagi et al., 2019).

In summary (refer to Table 1), prior studies stated that there is a strong relationship between project managers hired who employed to manage, lead the projects, that to results project management success, under the ability, responsibility and high skills, that they have, to 
achieve the iron triple constraint of any project management goals within the scope, project schedule, and budget cost of project. Therefore, success project management skills require a project manager qualifications, skills, and ability to deal with complex matter. Additionally successful project management requires the technical expertise of effective project managers, the ability to motivate, motivate, and lead of a project management team.

\begin{tabular}{|c|c|c|c|}
\hline Author & Year & Purpose & Findings \\
\hline Shahibi et al. & 2019 & $\begin{array}{l}\text { to Investigate the } \\
\text { important relationship } \\
\text { between project } \\
\text { success and iron } \\
\text { triangle management. }\end{array}$ & $\begin{array}{l}\text { Particularly, this theory affects the cost } \\
\text { and quality of a project that these two } \\
\text { changes contribute to the success of the } \\
\text { project. For example, project managers } \\
\text { should ensure that project costs always } \\
\text { determine the time and scope of } \\
\text { installation throughout the project } \\
\text { before starting a project. This allows } \\
\text { project managers to forecast, budget and } \\
\text { schedule plan of projects accurately. } \\
\text { The role of project manager in the } \\
\text { financial institution industry continues to } \\
\text { develop capacity in project management } \\
\text { structures, project planning, } \\
\text { implementation, monitoring and } \\
\text { management. This is because this is a } \\
\text { discipline that requires expertise and } \\
\text { superior technology. }\end{array}$ \\
\hline $\begin{array}{l}\text { Nilton Takagi } \\
\text { et al. }\end{array}$ & 2019 & $\begin{array}{l}\text { to describes the success } \\
\text { of project } \\
\text { management, the need } \\
\text { and importance of } \\
\text { processes that are } \\
\text { clearly integrated into } \\
\text { project management } \\
\text { practices, and provides } \\
\text { first tips on how to use } \\
\text { them in this process. }\end{array}$ & $\begin{array}{l}\text { Increasing the success rate of project } \\
\text { management is an organizational } \\
\text { challenge, so the purpose of the } \\
\text { integration model is to enhance and } \\
\text { factor in the resilience of project } \\
\text { management success as the focus of } \\
\text { project to integrate successful asset } \\
\text { management and management } \\
\text { processes into project design, } \\
\text { implementation and completion as well } \\
\text { as in the monitoring and controlling } \\
\text { activities. }\end{array}$ \\
\hline Henkel et al. & 2019 & $\begin{array}{l}\text { to explore Job } \\
\text { leadership and } \\
\text { relationships } \\
\text { Investigate leadership } \\
\text { behaviour to find out } \\
\text { how leadership } \\
\text { behaviour relates to the } \\
\text { performance of a } \\
\text { project manager in a } \\
\text { project team that is }\end{array}$ & $\begin{array}{l}\text { Leadership skills and styles can be learned } \\
\text { based on a high level of understanding } \\
\text { and self-esteem, which are key factors in } \\
\text { project success. It provides the skills to } \\
\text { work with project management leaders, } \\
\text { especially the ability to motivate, } \\
\text { motivate and lead project teams. }\end{array}$ \\
\hline
\end{tabular}




\begin{tabular}{|l|l|l|l|}
\hline & & $\begin{array}{l}\text { critical to the success of } \\
\text { a project. }\end{array}$ & \\
\hline $\begin{array}{l}\text { Alvarenga et } \\
\text { al. }\end{array}$ & 2018 & $\begin{array}{l}\text { Review the experts } \\
\text { involved in project } \\
\text { management to assess } \\
\text { the importance of } \\
\text { project managers to the } \\
\text { success of the project. }\end{array}$ & $\begin{array}{l}\text { The end realistic result is that project } \\
\text { manager must be aware of the } \\
\text { awareness and commitment and the next } \\
\text { pressure to maintain mental and } \\
\text { emotional health under the pressure of } \\
\text { continued success. }\end{array}$ \\
\hline al. & $2017 \begin{array}{l}\text { to specify project } \\
\text { management success } \\
\text { strategies to improve } \\
\text { project cost and project } \\
\text { schedule information } \\
\text { system and project } \\
\text { development } \\
\text { efficiency. }\end{array}$ & $\begin{array}{l}\text { Thesults show that large IS projects are } \\
\text { a strategic investment in the business, } \\
\text { and because of the use of effective and } \\
\text { efficient management methods, thus } \\
\text { Improve project management success. } \\
\text { Surprisingly, the results reveal that the } \\
\text { role of the project manager does not } \\
\text { affect the outcome of the project, } \\
\text { suggesting that the senior project } \\
\text { manager is not a senior staff will not } \\
\text { necessarily be the best of project } \\
\text { managers }\end{array}$ \\
\hline
\end{tabular}

Table 1: Literature matrix on the relationship between project manager and project management success

\section{Discussion}

Finding from this paper suggest that project manager plays a significant role in project management success. as such, research studies has shown that the most capable and effective project managers have the ability to adapt their project management abilities to get the members demands of the project management team, stakeholders and specific requires in differ culture environments ( Mulcahy, 2018).

Also, institutions can be used to set development goals, so they can continue to operate to ensure significant and systematic investment by project managers and project management teams with a sustained focus on political issues and culture environmental, to lead toward organization growth for prospective success to project management (Amanchukwu, Stanley, \& Ololube, 2015; Arora \& Baronikian, 2013).

In addition, the current study provides useful information to identify the project manager role as an important factor that influences the relationship of project management success with a qualified, skilled project manager which must concentrate on by both researchers and practitioners within this domain. On another way, if you do not take this aspect seriously, it can lead to project failure of project management, accordingly, the project manager is heavily used in projects in different construction industries, so understanding the role of the project manager success, it is important, is vital to identifying the role of project manager 
contributions to the successful implementation of a project. Hence, the importance of this role as the project progresses through the implementation phase.

\section{Conclusion}

This research paper discussed that the capability of project manager on project team management, such as project activities planning; project team member skill evaluation and job distribution; knowledge on Use technology and project management tools; also, discussed how the project managers deal with political and cultural issues as the key elements for project success, as well, helps project managers to find an engaging and open approach to learning about projects management, how to deal with stakeholder needs, and senior executives involved in project management success.

Hence, this research paper will provide the institution, companies with large scale of understanding of the role of project manager and supports the development of project management courses and training programs to better understand how students handle all types of projects, and to fine tune their abilities and personal skills type to fit project manager responsibilities. Thus, skills can be learned from advanced knowledge and self-awareness, which are the key to successful project management (Stine, 2018).

As a result, of this research paper can provide a based essential recommendation towards the development of the project manager role leading project management success. However, these study suggestions important approach regarding to project manager role required and his relationship with project management success throughout the implementation phase, this includes projects that require leadership, technical training and development within companies.

Therefore, if the organizations taken seriously how to deal, and supporting the project managers by rising skills, high level of training courses, then organizations, companies will guarantee projects handover on time and get more projects profits and good reputation.

\section{Acknowledgements}

This work was supported/funded by the Ministry of Higher Education under Fundamental Research Grant Scheme (FRGS/1/2019/SS03/UTM/02/8).

\section{References}

Arora, M., \& Baronikian, H. (2013), Leadership in project management (2nd ed). Canada: Leadership Publishing House.

Burgan, C., \& Burgan, S. (2014), one size does not fit all: Choosing the right project approach. Project Management Institute Global Congress 2014-North America.

Chipulu, M., Neoh, G., Ojiako, U., Williams, T. (2013), a multidimensional analysis of project manager competencies, IEEE Transactions on Engineering Management, Vol. 60 No. 3, pp. 506-517.

Dow, W., Taylor, B. (2015). Project management communication tools (1st ed.). Dow Publishing LLC: Renton, WA.

Duncan, W. R. (2000).A Guide to the Project Management Body of Knowledge, 2000 Edition, Newton Square, Project Management Institute. 
Elakouri, K. M. (2018), The establishment of a training and development framework system for the Libya's oil industry, Nottingham Trent University

Garel. (2013), A history of project management models: From pre-models to the standard models, Int. J. Project Manage., vol. 31, no. 5, pp. 663-669, Jul. 2013.

Gandomani, Tavakoli, Zulzalil, Farsani. (2020), The Role of Project Manager in Agile Software Teams, IEEE, Faculty of Computer Science and Information Technology, University Putra Malaysia, Malaysia.

Henkel, G., Marion, W., \& Bourdeau, T. (2019). Project Manager Leadership Behavior: TaskOriented Versus Relationship-Oriented. Journal of Leadership Education, https://doi.org/10.12806/V18/I2/ R8.

Hardy-Vallee, B. (2012), How to run a successful project. Retrieved from https://news.gallup.com/ businessjournal/152756/run-successful-project.aspx.

Huemann, Keegan, Turner. (2017), Human resource management in the project-oriented organization," Int. J. Project Manage., vol. 26, no. 5, pp. 577-585, 2018.

Jeferson, A., Branco, B. V., Pereira, W., \& Silveira. (2018), A Revaluation Of The Criticality Of The Project Manager To The Project's Success, Business Management Dynamics Vol.8, No.2, Aug 2018, pp.01-18.

Jones, E. (2018). Honing interpersonal skills for successful project delivery.[Blog post]. Retrieved from https://www.pm4ngos.org/2018/04/14/honing-interpersonal-skillsfor-successful-project-delivery/.

Kerzner. (2013), Project Management: A Systems Approach to Planning, Scheduling, and Controlling, Hoboken, NJ, USA: Wiley, 2013.

Kerzner, H. (2013), Project management: a systems approach to planning, scheduling, and controlling, 11th edition. John Wiley \& Sons, Hoboken, N. J.

Lindblad, M. (2014). Project manager skills \& personality characteristics. Retrieved from http://everydaylife,globalpost.com/project-manager-skills-personality-characteristics13166.html.

Loufrani-Fedida, and Missonier. (2015), The project manager cannot be a hero anymore! Understanding critical competencies in project-based organizations from a multilevel approach, International Journal of Project Management, Vol. 33 No. 6, pp. 1220-1235.

Meredith and Mantel. (2011), Project Management: A Managerial Approach. Hoboken, NJ, USA: Wiley, 2011.

Murthy, A., \& Sreenivs, S. (2017). Does people behavior impact projects? How? And what do we do about it? PM Times: Resources for Project Managers. Retrieved from, https://www.projecttimes.com/articles/doespeople- behavior-impact-projects-howand-what-do-we-do-about-it.html.

Miterev, Mancini, Turner. (2017), Towards a design for the project based organization, Int. J. Project Manage., vol. 35, no. 3, pp. 479-491, doi: 10.1016/j.ijproman.2016.12.007.

Mulcahy, R. (2018). PMP exam prep (9th ed.). RCM Publications Inc.: Minnetonka, MN.

Radujkovića, S. (2017), Project Management Success Factors, Creative Construction Conference 2017, CCC 2017, 19-22 June 2017, Primosten, Croatia,

Sanchez, Terlizzi. (2017), Cost and time project management success factors for information systems development projects, Elsevier Ltd. APM and IPMA.

Prasad, S., Tata, J., Herlache, L., McCarthy, E. (2013), Developmental project management in emerging countries, Oper. Manag. Res. 6 (1-2), 53-73.

Project Management Institute (2013). A Guide to Project Management Body of Knowledge (PMBOK); 4th Edition. 
PMBOK Guide. (2017). A guide to the project management body of knowledge (6th ed.). Newtown Square, PA: Project Management Institute.

Rolstadås, Tommelein, Schiefloe, Ballard. (2014), Understanding project success through analysis of project management approach, International Journal of Managing Projects in Business 7(4): 638-660. doi:10.1108/IJMPB-09-2013-0048.

Snyder, C. (2012). Manage to lead: Flexing your leadership style. Newtown Square, PA: Project Management Institute.

Stine, J. (2018). How self-awareness makes you a better manager. [Blog post]. Retrieved from https://www.extension.harvard.edu/professional-development/blog/how-selfawareness-makes-you-better-manager.

Turner, J. (2014), The Handbook of Project-based Management: Leading Strategic Change in Organizations, 3th ed. McGraw-Hill Education. 